\title{
Addiction and Devotion in Early Modern England
}


This page intentionally left blank 


\section{Addiction and Devotion in Early Modern England}

52

Rebecca Lemon

$\overline{\text { PENN }}$

UNIVERSITY OF PENNSYLVANIA PRESS

P H I L A DE L P H I A 


\section{HANEY FOUNDATION SERIES}

A volume in the Haney Foundation Series, established in 196I with the generous support of Dr. John Louis Haney.

Copyright (C) 2018 University of Pennsylvania Press

All rights reserved. Except for brief quotations used for purposes of review or scholarly citation, none of this book may be reproduced in any form by any means without written permission from the publisher.

$$
\begin{gathered}
\text { Published by } \\
\text { University of Pennsylvania Press } \\
\text { Philadelphia, Pennsylvania I9IO4-4II2 } \\
\text { www.upenn.edu/pennpress }
\end{gathered}
$$

Printed in the United States of America on acid-free paper I 3579 IO 8642

A Cataloging-in-Publication record is available from the Library of Congress ISBN 978-0-8I22-4996-5 
To Marc and Jasper 
This page intentionally left blank 